\title{
The Cordilleran Ice Sheet in Northern British Colombia
}

L'Inlandsis de la Cordillère dans le nord de la

Colombie-Britannique

Die Kordilleren-Eisdecke im Norden von British Columbia

\section{June M. Ryder et Denny Maynard}

Volume 45, numéro 3, 1991

L'Inlandis de la Cordillère

The Cordilleran Ice Sheet

URI : https://id.erudit.org/iderudit/032881ar

DOI : https://doi.org/10.7202/032881ar

Aller au sommaire du numéro

\section{Éditeur(s)}

Les Presses de l'Université de Montréal

\section{ISSN}

0705-7199 (imprimé)

1492-143X (numérique)

Découvrir la revue

Citer cet article

Ryder, J. M. \& Maynard, D. (1991). The Cordilleran Ice Sheet in Northern British Colombia. Géographie physique et Quaternaire, 45(3), 355-363.

https://doi.org/10.7202/032881ar

\section{Résumé de l'article}

Les dates recueillies sur les laves associées aux tills et aux erratiques montrent que des glaciations de grande envergure se sont manifestées entre 4 et 0,6 Ma $\mathrm{BP}$. Les quelques datations au radiocarbone disponibles indiquent que la chronologie de l'inlandsis du Wisconsinien supérieur (Glaciation de Fraser) était semblable au nord comme au sud de la Colombie-Britannique. Au cours de ia longue phase initiale de la glaciation, le Lac Stikine était endigué par l'avancée de glaciers de vallée de la chaîne Côtière et par des glaciers alpins en provenance du plateau intermontagnard. À l'optimum de la Glaciation de Fraser, le réseau d'écoulement glaciaire était dominé par l'écoulement à partir d'un névé centré sur le nord des monts Skeena. La déglaciation s'est faite en partie par le retrait de langues glaciaires et en partie par la fonte de glace stagnante. Les moraines de retrait montrent qu'il y a eu une ou plusieurs récurrences ou haltes de la marge glaciaire. Pendant la déglaciation, (a vallée de la Stikine River était occupée par un glacier de décharge actif et un réseau de drainage sous-glaciaire important.
Tous droits réservés ㄷ Les Presses de l'Université de Montréal, 1991

Ce document est protégé par la loi sur le droit d'auteur. L'utilisation des services d'Érudit (y compris la reproduction) est assujettie à sa politique d'utilisation que vous pouvez consulter en ligne.

https://apropos.erudit.org/fr/usagers/politique-dutilisation/ 


\section{THE CORDILLERAN ICE SHEET IN NORTHERN BRITISH COLUMBIA}

June M. RYDER and Denny MAYNARD, Department of Geography, University of British Columbia, Vancouver, British Columbia V6T 1W5; 251 West 14th Street, \#13, North Vancouver, British Columbia V7M 1 P4.

ABSTRACT Dates from lavas associated with tills and erratics indicate that ice-sheet glaciations occurred between 4 and $0.6 \mathrm{Ma} \mathrm{BP}$. The few radiocarbon dates that are available suggest that the chronology of the Late Wisconsinan (Fraser Glaciation) ice sheet of northern British Columbia was similar to that of the southern part of the province. During what may have been a long, early phase of this glaciation, Glacial Lake Stikine was dammed by advancing valley glaciers in the Coast Mountains, and alpine glaciers developed on the intermontane plateau. At the climax of Fraser Glaciation, ice-flow patterns were dominated by outflow from a névé centred over the northern Skeena Mountains. Deglaciation occurred partly by frontal retreat of ice tongues and partly by downwasting of stagnant ice. Recessional moraines mark one or more resurgences or stillstands of the ice margin. During deglaciation, Stikine River valley was occupied by an active outlet glacier and a major subglacial drainage system.
RÉSUMÉ L'Inlandsis de la Cordillère dans le nord de la Colombie-Britannique. Les dates recueillies sur les laves associées aux tills et aux erratiques montrent que des glaciations de grande envergure se sont manifestées entre 4 et 0,6 Ma BP. Les quelques datations au radiocarbone disponibles indiquent que la chronologie de l'inlandsis du Wisconsinien supérieur (Glaciation de Fraser) était semblable au nord comme au sud de la ColombieBritannique. Au cours de la longue phase initiale de la glaciation, le Lac Stikine était endigué par l'avancée de glaciers de vallée de la chaîne Côtière et par des glaciers alpins en provenance du plateau intermontagnard. A l'optimum de la Glaciation de Fraser, le réseau d'écoulement glaciaire était dominé par l'écoulement à partir d'un névé centré sur le nord des monts Skeena. La déglaciation s'est faite en partie par le retrait de langues glaciaires et en partie par la fonte de glace stagnante. Les moraines de retrait montrent qu'il y a eu une ou plusieurs récurrences ou haltes de la marge glaciaire. Pendant la déglaciation, la vallée de la Stikine River étaít occupée par un glacier de décharge actif et un réseau de drainage sous-glaciaire important.
ZUSAMMENFASSUNG Die KordillerenEisdecke im Norden von British Columbia. Daten von Laven, die in Verbindung mit Grundmoränen und erratischen Blöcken gebracht werden, zeigen, dass es zwischen 4 und 0.6 Ma v.u.Z. zu Eisdecke-Vereisungen gekommen ist. Die wenigen zur Verfügung stehenden Radiokarbondaten legen nahe, dass die Chronologie der spätwisconsinischen (Fraser-Vereisung) Eisdecke im Norden von British Columbia derjenigen des südlichen Teils der Provinz ähnlich war. Während einer Periode, die eine lange, frühe Phase dieser Vereisung gewesen sein könnte, war der glaziale See Stikine durch in den Küstenbergen vorrückende Talgletscher gestaut, und alpine Gletscher entwickelten sich auf dem Plateau zwischen den Bergen. Während des Höhepunkts der Fraser-Vereisung wurden die Eisströmungsmuster durch den Ausfluss von einem Firnfeld mitten über den nördlichen Skeena-Bergen beherrscht. Die Enteisung geschah teilweise durch frontalen Rückzug der Eiszungen und teilweise durch Abzehrung von stagnierendem Eis. Rückzugsmoränen markieren eine oder mehrere Rückvorstösse oder einen Stillstand des Eisrands. Während der Enteisung befand sich im Stikine-Flusstal ein Gletscher mit aktivem Austritt und einem bedeutenden subglazialen Dränage-System. 


\section{INTRODUCTION}

The objective of this paper is to review the current status of knowledge about the Cordilleran Ice Sheet in northern British Columbia, and to present some of our own previously unpublished observations. Little work has been oriented specifically toward the Quaternary history and glacial geomorphology of this area. Consequently, some of the generalizations and conclusions that we present here are tentative because they are based on relatively sparse data. However, sufficient information does exist to permit reconstruction of some of the overall characteristics of the ice sheet and to make comparisons with southern British Columbia.

The concept of a "great confluent ice-mass" over northern British Columbia was initiated by G. M. Dawson in the late nineteenth century. During the first half of this century, information about Pleistocene geology and glacial features was reported by the geologists who carried out exploration and mineral resource assessment, such as F. A. Kerr, G. Hanson, and W. A. Johnston. Later, some geologists engaged in bedrock mapping, most notably $\mathrm{H}$. Gabrielse and J. O. Wheeler, also recorded observations on striae, erratics, and other glacial features. Most recently, Pleistocene sediments and landforms have been studied by the writers and other persons working for the British Columbia government and private companies during the course of terrain inventory mapping and environmental impact studies.

This study encompasses that part of British Columbia that lies north of $55^{\circ} \mathrm{N}$ and west of the Rocky Mountain Trench
(Fig. 1). It includes two major mountain belts, the Coast Mountains and the Cassiar-Omineca Mountains, and the intervening high plateaus (Holland, 1964). Several major river systems, such as the Stikine, Skeena, Liard and Finlay, rise on the plateaus and flow through the bordering mountains.

\section{CHRONOLOGY}

There is very little chronological information for this part of the Cordilleran Ice Sheet, but what is available suggests a history of glaciations similar to that of southern British Columbia. Evidence that an ice sheet existed at times during the late Pliocene and early Pleistocene comes from dates on lavas that were erupted during glaciation. On Mount Edziza, till and glaciofluvial sediments containing erratics are interbedded with lava flows and pyroclastic deposits that date back to 3 or $4 \mathrm{Ma} \mathrm{BP}$ (Souther et al., 1984). Dates from the Level Mountain Range indicate that glaciation occurred before $4.5 \mathrm{Ma}$ BP (Hamilton, 1981). In the Grand Canyon of Stikine River, basal lavas $0.4 \mathrm{Ma}$ old (P. B. Read, personal communication) overlie glacially scoured rock surfaces and glaciofluvial gravels (Kerr, 1948).

Considering the apparent antiquity of these older glaciations, the subsequent glacial record is sparse. In fact, several people noted no evidence of multiple glaciation (e.g., Watson and Mathews, 1944; Kerr, 1948; Lambert, 1974). Stratigraphic evidence of two glaciations, or of one drift unit plus morphological features ascribed to an earlier glaciation, has been recorded at a few scattered localities (Gabrielse, 1963;

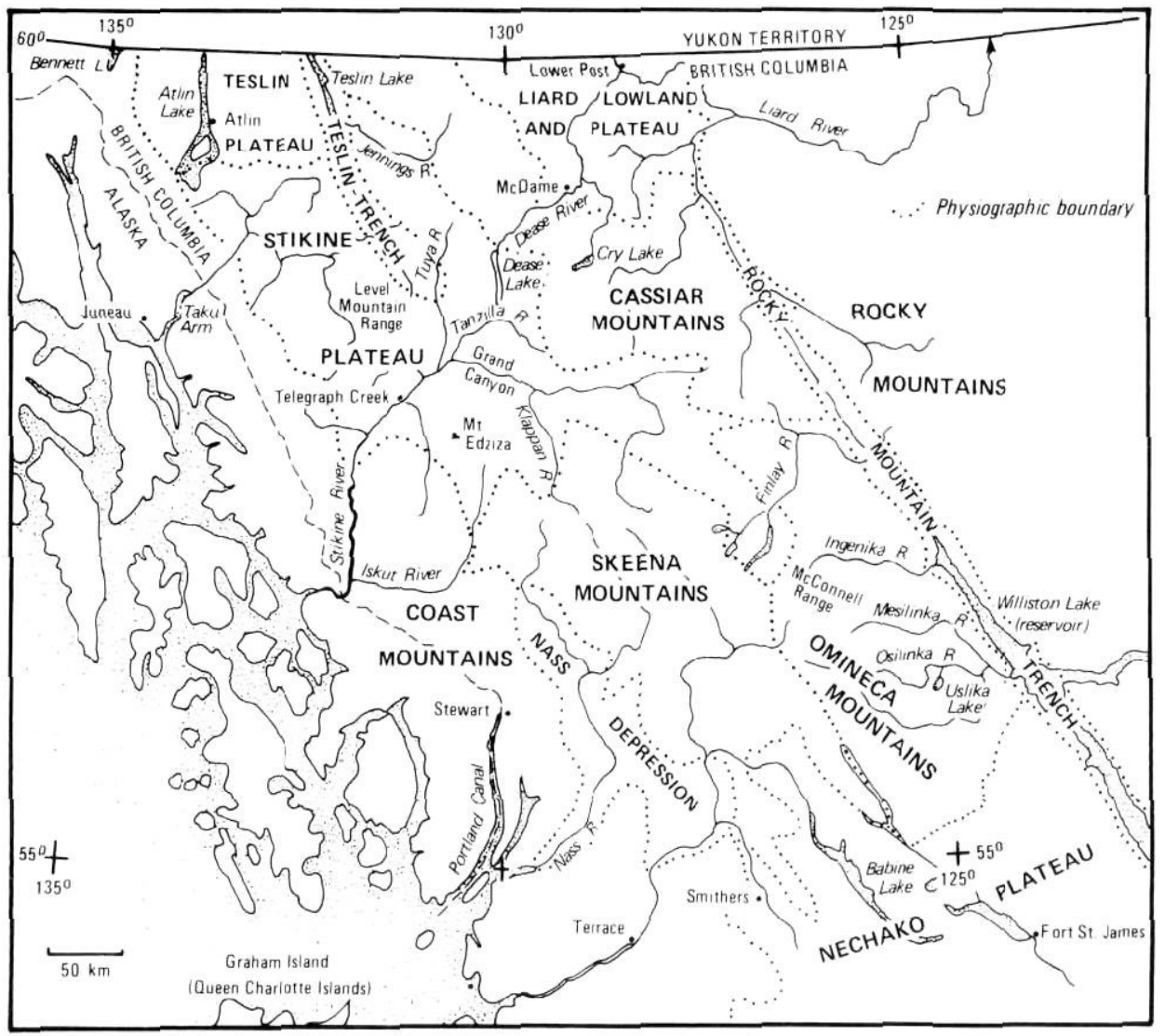

FIGURE 1. Location map and physiographic regions (from Mathews, 1986).

Carte de localisation et régions physiographiques (d'après Mathews, 1986). 
Johnston, 1926a; 1926b; Kerr, 1948). In the Atlin area, two distinct, fresh-looking tills and associated outwash overlie a third till and outwash (Aitken, 1959). Radiocarbon dates from peat suggest that the lowest till, which is strongly oxidized (Aitken 1959), may be older than 37000 years (Miller, 1976). The stratigraphy at Atlin is complex (Aitken, 1959) and has not been fully described however, so these results should be interpreted with caution (Clague, 1981). Other evidence for non-glacial conditions during Middle Wisconsinan time comes from Babine Lake where dates of about 34000 and 43000 years were obtained on a mammoth bone and wood from organic-rich silts (Harington et al., 1974). Data gathered in the Rocky Mountain Trench (Rutter, 1977) and in the southern Yukon (Klassen, 1987) also substantiate pre-Late Wisconsinan glaciation. These few radiocarbon dates suggest that the glacial stages defined for southern British Columbia, i.e., the Middle Wisconsinan Olympia non-glacial interval and the Late Wisconsinan Fraser Glaciation (cf., Clague, 1981), also apply to this more northerly area.

There is additional stratigraphic evidence, but no absolute dating, of two advances of Cordilleran ice. Whether these were two stades of Fraser Glaciation, as in the case of the two upper tills at Atlin, or whether they represent two distinct glaciations, is not known. For example, in the Omineca Mountains near Uslika Lake, glaciolacustrine silts that were deposited in a moraine dammed lake are overlain by till (Roots, 1954). In the Dease River valley, two ice advances are suggested by a sequence where till is overlain by lake silts with a superimposed esker complex (Gabrielse, 1963). Johnston (1926b) noted evidence for an "interglacial" along Stikine River near Telegraph Creek.

Similarly, several workers have interpreted morphological features, such as moraines in the Atlin area, as evidence that an "older" (i.e., pre-Fraser) glaciation was more extensive than the most recent glaciation (Tallman, 1975; Miller, 1976). However, in the absence of absolute dating, these landforms, which occupy relatively distal positions with respect to ice-flow directions, cannot be reliably distinguished from those of an earlier stade of Fraser Glaciation.

\section{CORDILLERAN ICE SHEET DURING FRASER GLACIATION}

In general, the characteristics of the northern part of the Late Wisconsinan Cordilleran Ice Sheet in British Columbia were similar to those of its more southerly part, but there were some interesting dissimilarities.

\section{EARLY PHASE}

As in southern British Columbia (cf., Ryder and Clague, 1989, p. 57; Ryder et al., 1991), several workers have noted that development of the last ice sheet appears to have been preceded by an episode of alpine glaciation that was sufficiently long for the development (or redevelopment) of erosional landforms. Well developed but overridden cirques and rounded arêtes are the chief evidence cited for this by Aitken (1959). Gabrielse (1963) noted that spurs are generally rounded and some cirque headwalls have been modified by meltwater erosion in the Cassiar Mountains. In general, mountain landscapes are dominated by fresh-appearing landforms of alpine glaciation, suggesting that the erosional effects of the overriding ice sheet were minor.

It has been commonly suggested that during the build up of the ice sheet, ice expanded outward from accumulation zones in the Coast and Cassiar Mountains (cf., Kerr, 1948; Anderson, 1970; Davis and Mathews, 1944), but in fact, the pattern of ice sheet growth may have been more complex than this. Ice build up due to the growth of cirque and valley glaciers can be assumed to have occurred in the Coast Mountains and the higher parts of the Skeena Mountains because icefields and glaciers exist here at the present time. The presence of wellformed (but now empty) cirques and troughs in the Skeena Mountains, Cassiar Mountains and many parts of the Stikine Plateau (Fig. 2), indicates that alpine glaciers probably also developed and expanded in these areas. That ice accumulated in the interior plateau region is a noteworthy point of dissimilarity between northern and southern British Columbia (cf., Ryder et al., 1991).

If glaciers expanded from many centres of ice accumulation, then ice sheet morphology and flow patterns at the time of coalescence would have been complex. It has been suggested (e.g., Kerr, 1948) that, in some areas, regional ice flow directions reversed at times due to changes in the volume of ice flowing from the mountains relative to outflow from an intermontane ice dome. These interpretations are hard to substantiate in the absence of detailed mapping of erratics. However, local shifts in ice flow directions did occur during ice build up and/or during deglaciation due to changes in the relative influence of topographic control on thickening and thinning ice. For example, Watson and Mathews (1944) described intersecting striae and hillocks with "dritt tails on both... sides" in the Tuya-Teslin area.

\section{GLACIAL LAKE STIKINE}

The stratigraphy of bluffs alongside Stikine River suggests that a lake occupied Stikine valley during the early part of Fraser Glaciation. It is likely that the river was impounded by advancing glaciers in the Coast Mountains (Fig. 3). The vast

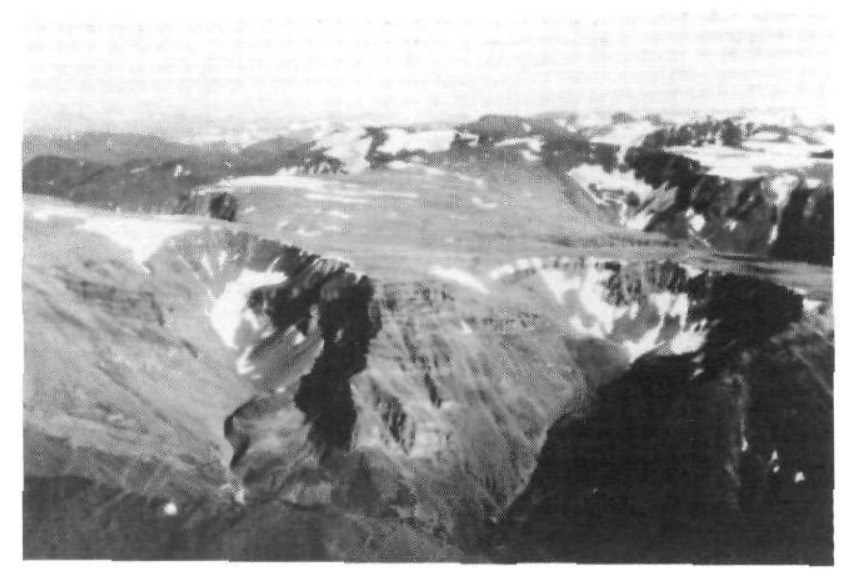

FIGURE 2. Cirques along the north-facing edge of the dissected Stikine Plateau near Iskut River.

Cirques le long de la bordure nord du plateau disséqué de Stikine, près de la lskut River. 
extent of the resulting lake, which we refer to as "Glacial Lake Stikine", is indicated by the distribution of thick glaciolacustrine sediments. We have traced these sediments along Stikine River and its major tributaries from Telegraph Creek to east of Klappan River, including through the Grand Canyon of the Stikine (Fig. 4), over a distance of more than $200 \mathrm{~km}$ and up to an elevation of at least $900 \mathrm{~m}$. Previous workers who noted the silts ascribed them to a late, rather than to an early, phase of the last glaciation and, Dawson suggested that the northerly (Dease Lake) arm of the glacial lake was blocked by Cassiar Mountain ice (e.g., Dawson, 1888, 1889; Kerr, 1948). A smaller

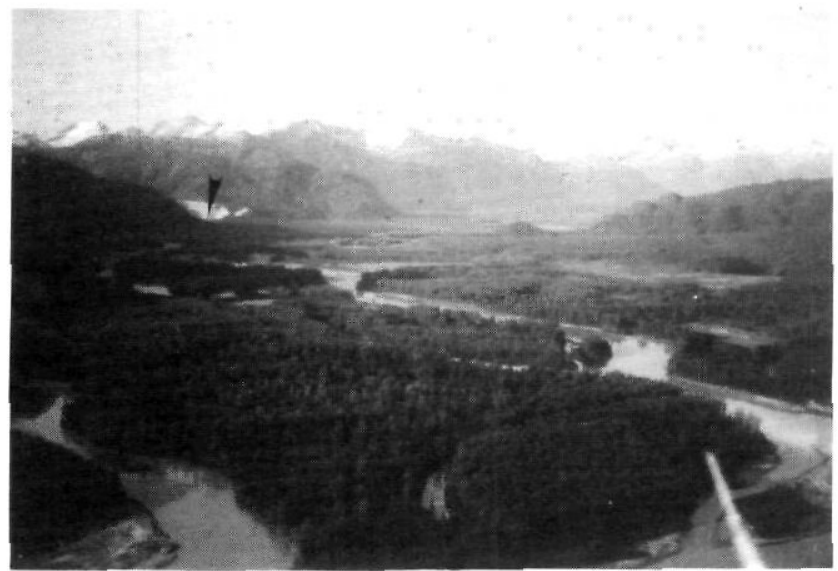

FIGURE 3. Stikine River valley in the Coast Mountains: view upstream. The close proximity of modern glaciers to Stikine River is indicated by the position of the Little Ice Age moraine of Mud Glacier (arrow).

Vue vers l'amont de la vallée de la Stikine River, dans la chaîne Cótière. La proximité des glaciers modernes est indiquée par la position de la moraine du Petit Âge glaciaire du glacier Mud (flèche).

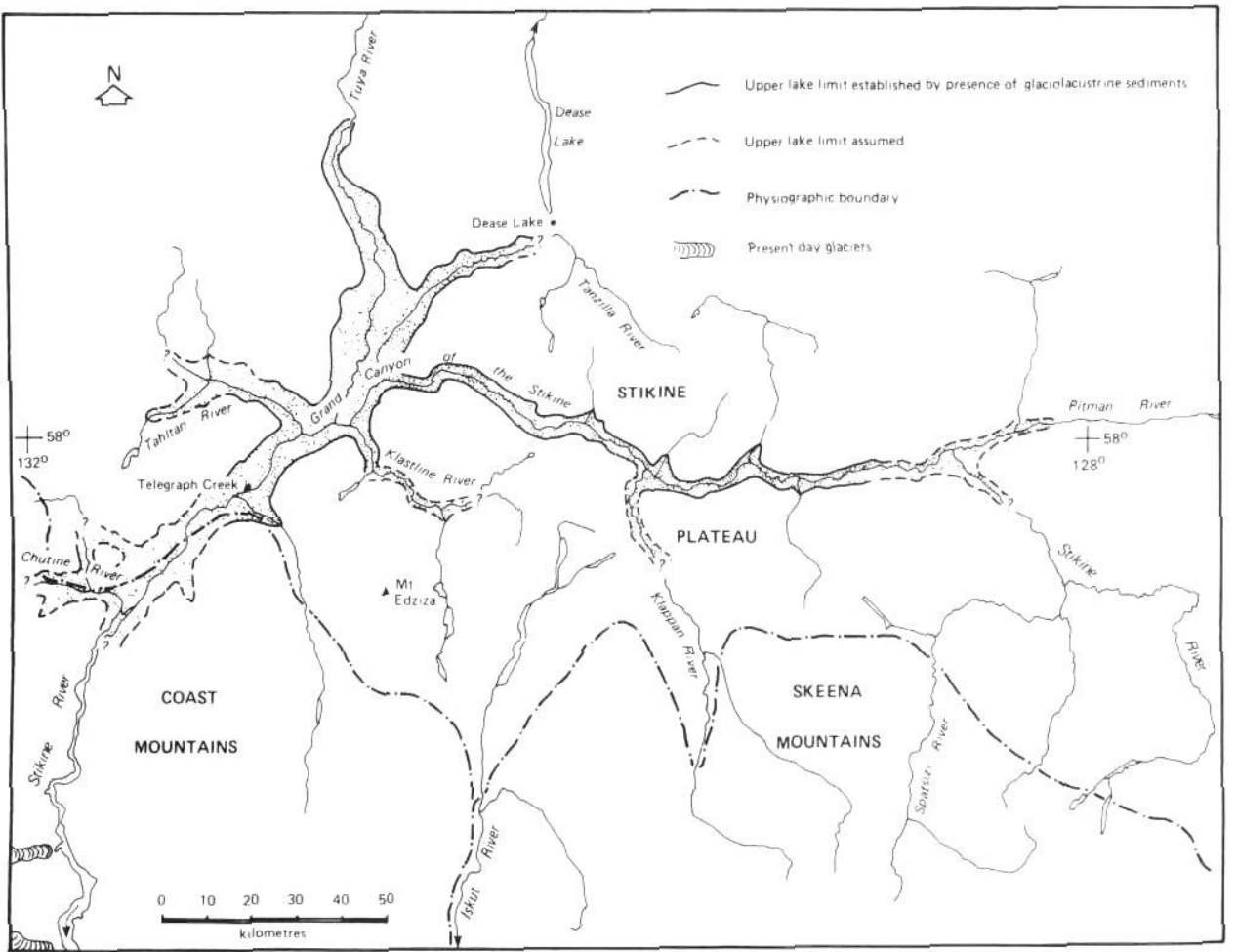

version of Glacial Lake Stikine was added to the Glacial Map of Canada (Prest et al., 1967) by W. H. Mathews.

The numerous sections in Stikine River valley show horizontally bedded silts that are many tens of metres in thickness. They are overlain by a well consolidated, silty till that is a few metres thick (Fig. 5). The relatively great thickness of these sediments suggests that Glacial Lake Stikine may have existed for a considerable length of time, supporting the concept that a long phase of mountain glaciation preceded development of the ice sheet.

Similar lakes may have existed during early Fraser Glaciation in the valleys of other rivers that cross the Coast Mountains where, as in Stikine valley, glacier advances from tributary valleys could block the trunk streams. Cursory stratigraphic observations by the writers in the Iskut and Nass basins suggest that this was the case. Glacial lakes also formed during ice advance in some eastward-draining valleys, such as those of Dease River (Gabrielse, 1963) and Uslika Lake (Roots, 1954).

\section{CLIMAX CONDITIONS}

Figure 6 illustrates our reconstruction of ice flow directions at the climax of Fraser Glaciation. Original data on the orientation of striations, grooves, and drumlins (see references on Fig. 6) were compiled on a 1:2 million scale map, and then generalized to show the major flow patterns. Most ice flow features appear to indicate directions at the glacial maximum because features on high ridge crests are generally parallel with adjacent features at lower elevations. Our results confirm and extend the patterns shown on the Glacial Map of Canada (Prest et al., 1967; Fig. 1.12 in Clague, 1989) but differ somewhat from those shown on recent palaeogeography maps by Dyke and Prest (1986).
FIGURE 4. Map showing the extent of Glacial Lake Stikine. The ice dam was in the Coast Mountains.

Carte montrant l'étendue du Lac Stikine. Le barrage de glace était situé dans la chaîne Côtière. 
An interesting pattern of ice flow is apparent (Fig. 6). We do not demonstrate significant outflow from the Coast and Cassiar mountains. In fact, outflowing ice from these mountains appears to have covered a relatively small area. A continuous ice divide did not exist along the Coast Mountains. Rather, ice flow for this whole sector of the ice sheet appears to have been dominated by radial flow from the northern Skeena Mountains (the area bordered by the upper Stikine, Klappan, upper Nass,

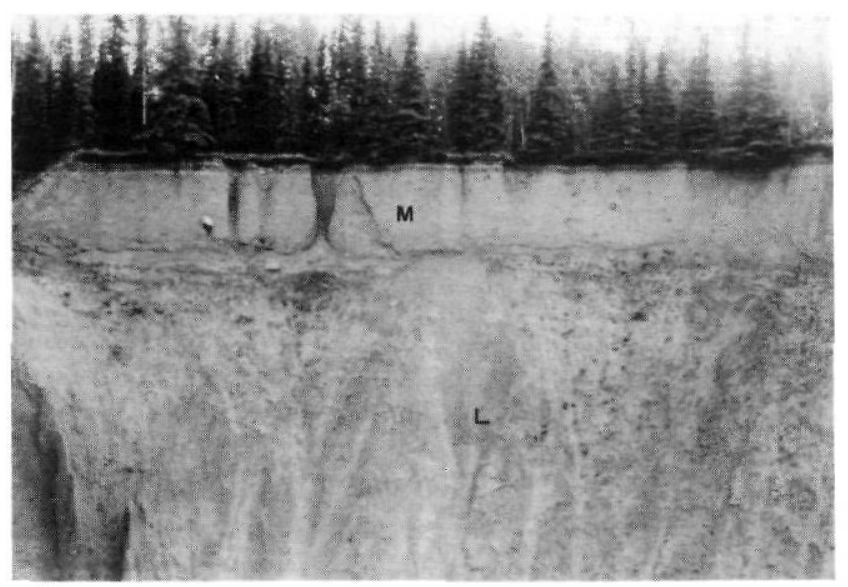

FIGURE 5. Section in river bluff near Tanzilla-Stikine confluence shows till ("T") overlying thick glaciolacustrine silt ("L").

Une coupe dans la falaise de la rivière près de la confluence TanzillaStikine montre que le till (T) surmonte un silt glaciolacustre épais (L). and Finlay rivers). A broad ice stream (sensu lato) flowed northward through the southern half of the Cassiar Mountains, and turned eastward across the Liard Lowlands toward the eastern edge of the ice sheet. A second major stream of ice, marked by extensive streamlined topography, flowed northwestward to the Teslin Depression and into the Yukon where it formed the "Cassiar Lobe" of Wheeler (1961). Ice streams flowed southward through the Nass Depression and the valleys of Takla and Babine lakes. South of Finlay River, ice flowed eastward to join southward-flowing ice in the Rocky Mountain Trench. North of the Finlay, ice flow was northward and northwesterly to the Liard Lowland. The northern Cassiar Mountains also appear to have been an ice accumulation zone; from here, ice flowed southwestward to merge with the Teslin ice stream, and northeastward to the Liard stream.

There is very little evidence that ice moved eastward from the Coast Mountains accumulation zone, other than a single, well-defined northerly flowing ice stream in the Atlin Lake Taku Arm area. This contributed to the Coast Mountains Lobe in the Yukon (Wheeler, 1961).

In several places however, major outlet glaciers appear to have drained westward through the Coast Mountains to the Pacific coast. This is particularly clear in the case of the Taku region where converging flow lines suggest that a relatively rapidly discharging outlet glacier drained ice from a large sector of the ice sheet. Outlet glaciers also occupied the Stikine, Iskut, and Nass valleys, and other coastal troughs and fiords.

Minimum surface elevations of the ice sheet, based on highest erratics and striations, have been recorded for parts of the

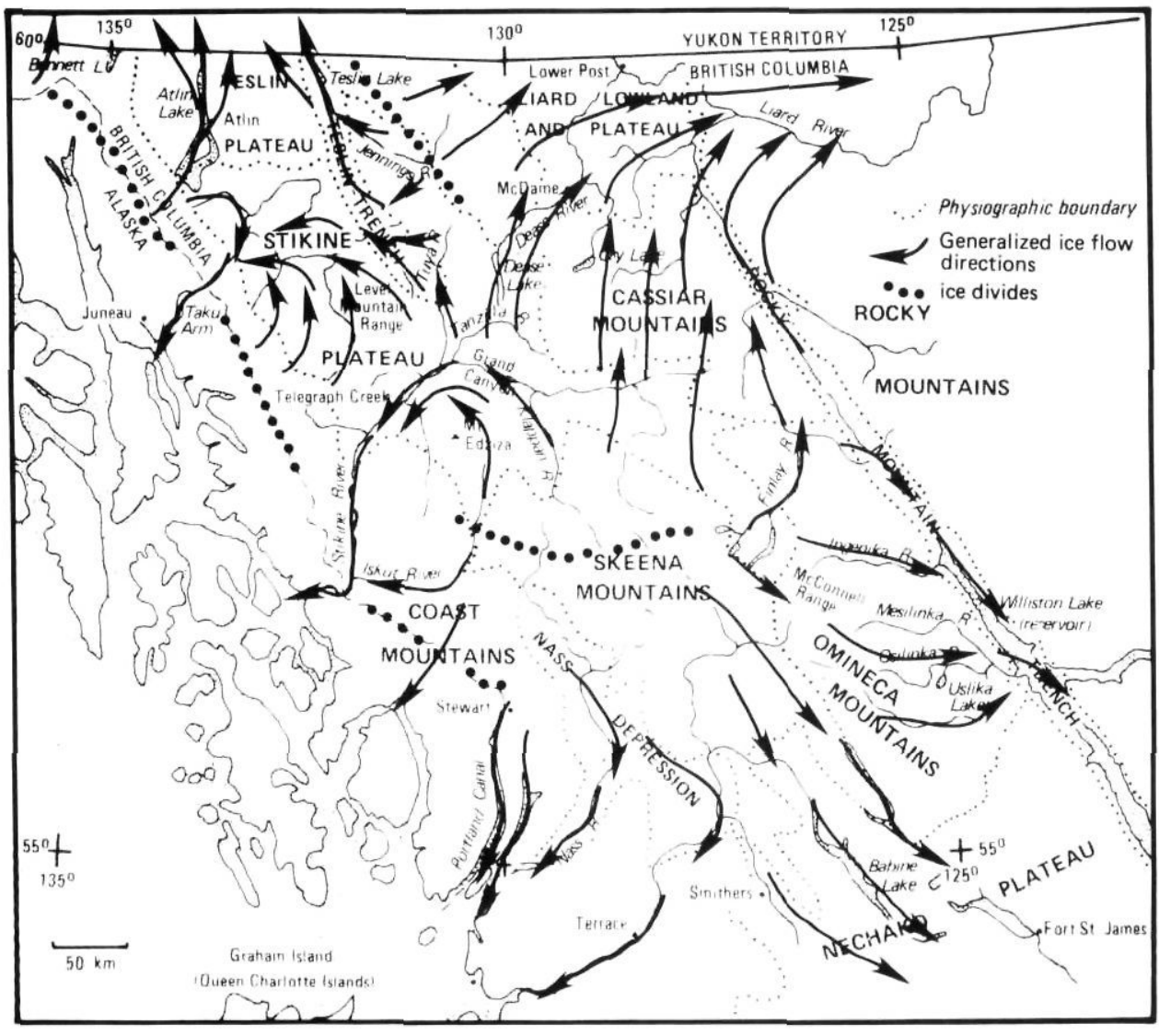

FIGURE 6. Generalized ice flow directions for the northern Cordilleran Ice Sheet at the climax of Fraser Glaciation. Generalized data from Aitken (1959), Armstrong (1949), Armstrong and Tipper (1948), Fenger (1982), Gabrielse (1963, 1968), Hanson and McNaughton (1936), Kerr (1934), Lay (1940), Lord (1948), Lacelle (1983), Mathews (1980), Roots (1954), Ryder (1981, 1983), Tallman (1975), Watson and Mathews (1944), Wheeler (1961).

Directions générales de l'écoulement glaciaire à partir du nord de I'Inlandsis de la Cordillère à l'optimum de la Glaciation de Fraser. Données de Aitken (1959), Armstrong (1949), Armstrong et Tipper (1948), Fenger (1982), Gabrielse (1963, 1968), Hanson et McNaughton (1936), Kerr (1934), Lay (1940), Lord (1948), Lacelle (1983), Mathews (1980), Roots (1954), Ryder (1981, 1983), Tallman (1975), Watson et Mathews (1944), Wheeler (1961). 
study area. However, these provide data that we judged to be insufficient for reconstruction of a true surface profile of the ice sheet. Recorded glacial limits range up to $2300 \mathrm{~m}$ in the Omineca Mountains (Roots, 1954) and $2100 \mathrm{~m}$ in the central Cassiar Mountains (Johnston, 1926b; Gabrielse, 1963). Elsewhere in the Omineca Mountains, and in the northern Nechako Plateau, elevations range from 1700 to 2000 m (Lay, 1940; Lord, 1948; Armstrong, 1949).

Taken together, the radial flow pattern and the relatively high glacial limit in the Omineca Mountains near the radial centre, suggest that some form of ice dome, although not one of continental proportions, probably existed over the northern Skeena Mountains. Lord (1948) suggested that in the McConnell Ranges of the upper Finlay River area, near the core of our proposed dome, ice flowed across ridges of $2100 \mathrm{~m}$ elevation. Observers in more peripheral regions have pointed out that the Cordilleran ice cover was at all times influenced by underlying topography, and that the "mountain ice sheet" never developed into a true "continental ice sheet" (i.e., with flow directions independent of underlying topography) during the last glaciation (Holland, 1940; Davis and Mathews, 1944; Watson and Mathews, 1944; Armstrong and Tipper, 1948; Roots, 1954). The existence of severely glaciated trunk valleys and through valleys is cited as strong evidence for a long period when ice completely filled these valleys but glacier flow was controlled by the valley walls.

\section{DEGLACIATION}

Deglaciation appears to have taken place partly by frontal retreat of active lowland ice lobes and valley glaciers, and partly by downwasting of stagnant ice. Flow directions changed in accordance with increasing topographic control as the ice thinned (e.g., Watson and Mathews, 1944). In general, ice receded in the up-flow direction (e.g., Gabrielse, 1963; Watson and Mathews, 1944). Recession of the various ice streams and ice lobes may not have occurred simultaneously: Tallman (1975) recorded evidence of slightly offset and locally competing ice lobes in the Atlin area.

In the intermontane plateaus and the Omineca and Cassiar mountains, there is considerable evidence of the mode of deglaciation. Meltwater channels of various kinds are abundant and can be used to work out sequential positions of the edge of the ice. Some sequences of lateral meltwater channels are particularly striking: ten, twenty or more parallel channels mark successive positions of the downwasting ice margin (Fig. 7).

Glaciofluvial features such as eskers, kames, delta kames, and outwash terraces, are extensive on valley floors and lowlands (cf., Roots, 1954; Gabrielse, 1963; 1968; Watson and Mathews, 1944). In the central Stikine Plateau, many meltwater channels contain eskers and some eskers trend obliquely across meltwater channels. These relations suggest that the channels originated as tunnel valleys, and that the eskers were formed subsequently, after partial closure. Especially well defined glaciofluvial terraces up to $45 \mathrm{~m}$ above present river level occur in the Ingenika, Mesilinka and Osilinka valleys. Smaller terraces occur at all elevations from valley floors to ridge crests above $2000 \mathrm{~m}$. Small bodies of glaciolacustrine sediments are widely distributed, indicating that numerous

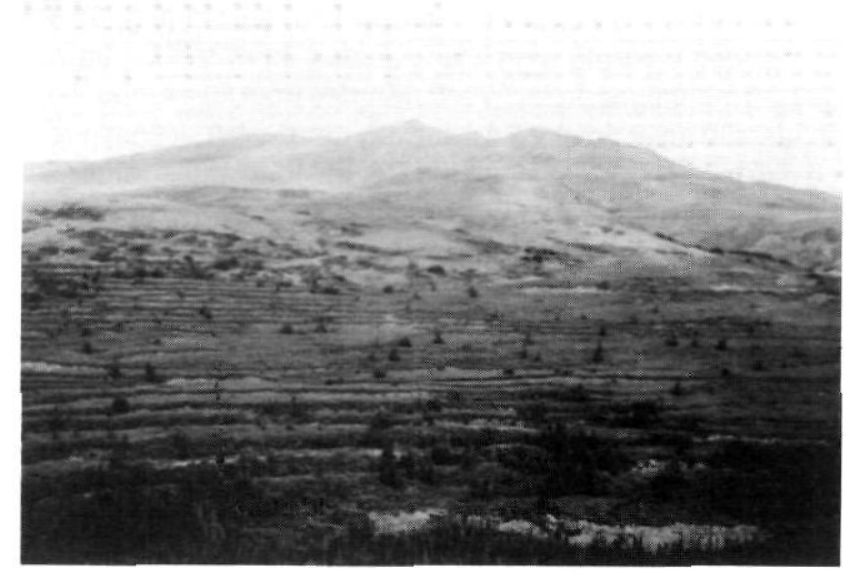

FIGURE 7. A series of lateral meltwater channels on the east side of the Teslin Trench.

Réseau de chenaux latéraux d'eaux de fonte sur le cóté est du Teslin Trench.

lakes existed during deglaciation (e.g., Watson and Mathews, 1944; Hanson and McNaughton, 1936). Large esker complexes, kettles, crevasse fillings, and thick glaciolacustrine silts are cited by Gabrielse (1963) as evidence that ice stagnation rather than frontal retreat was the dominant deglacial process in the Liard Lowland.

Analysis of these landforms of deglaciation could provide a means for detailed reconstruction of the mode of deglaciation and a basis for inferences about the thermal regime of the receding ice sheet. For example, the regularity and extent of parallel meltwater channels suggest that they may well have developed along ice margins where the glacier bed was frozen. Yet at lower elevations nearby, subglacial meltwater channels indicate an unfrozen bed. Possibly the ice was thermally stratified (cold over warm) during deglaciation.

We have found no evidence for a major ice-dammed lake in Stikine River valley during deglaciation. This is surprising because it might be expected that ice would have persisted in the Coast Mountains and dammed the through-flowing rivers, much as recessional lakes were impounded in the Thompson River system in southern British Columbia (cf., Fulton, 1969).

The absence of a recessional lake implies that the Stikine outlet glacier existed until deglaciation, but then it receded and thinned rapidly whilst meltwater from the contributing area of the ice sheet drained subglacially. Rapid recession of the glacier from the coast and through the Coast Mountains could have been triggered by rising sea level in conjunction with thinning ice. The marine limit in northern British Columbia is close to 180 m (Hanson, 1929; 1935; McConnell, 1913, Kerr, 1936; 1948). This suggests that for at least as far upstream as Telegraph Creek, now over $200 \mathrm{~km}$ from tidewater, shear stress at the base of the Stikine ice stream could have been reduced due to buoyancy effects, thus inducing high velocity and rapid ablation by calving.

Alongside Stikine River upstream from Telegraph Creek, numerous subglacial channels and eskers carried meltwater toward the trunk river (Fig. 8), indicating that it functioned as 


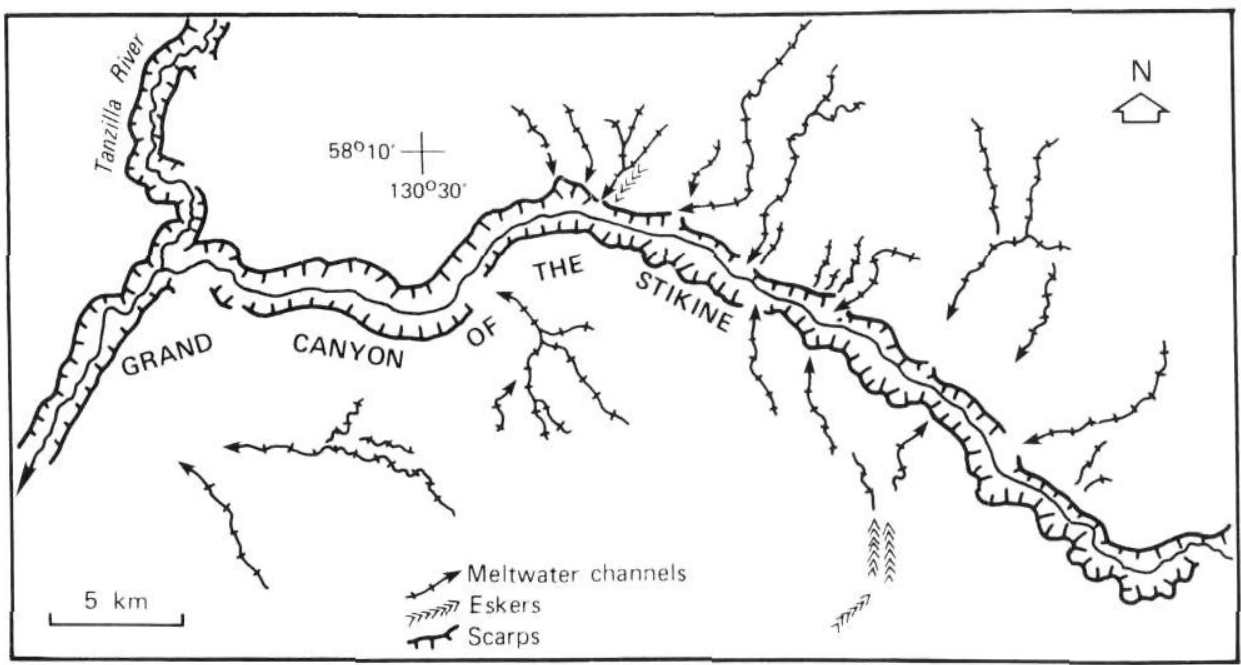

FIGURE 8. Major meltwater channels and eskers adjacent to the Grand Canyon of the Stikine (from Ryder, 1983).

Principaux eskers et chenaux d'eaux de fonte adjacents au grand canyon de Stikine (de Ryder, 1983).

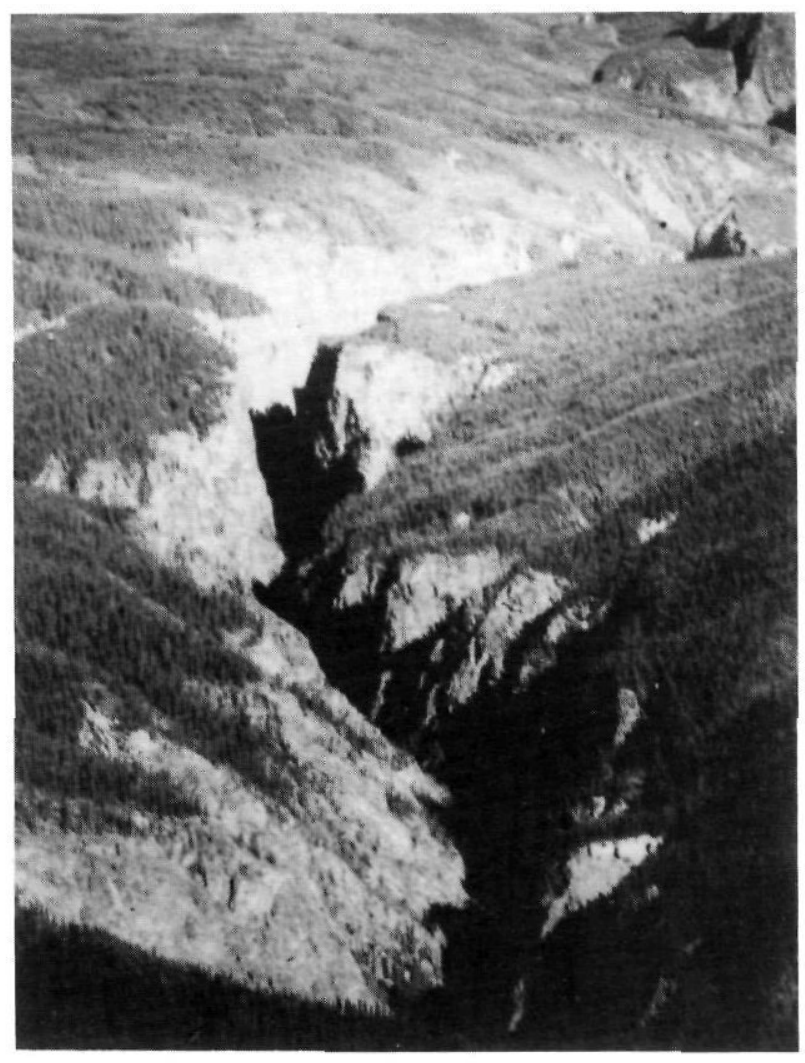

FIGURE 9. The Grand Canyon of the Stikine above the StikineTanzilla confluence (view downstream): the canyon is about $320 \mathrm{~m}$ deep here; its morphology is consistent with its origin as a subglacial meltwater channel.

Le grand canyon de Stikine au-dessus de la confluence StikineTanzina (vers l'aval); à cet endroit, le canyon a $320 \mathrm{~m}$ de profondeur. Sa morphologie actuelle rappelle le chenal de fonte sous-glaciaire d'origine. a major conduit under the ice sheet. Thus the postglacial Grand Canyon of the Stikine was probably initiated as a tunnel valley; certainly its morphology suggests that it could have been a subglacial channel (Fig. 9). Drawdown of the ice sheet in the Stikine basin due to rapid glacial discharge probably resulted in early deglaciation of the river channel, which then received meltwater subaerially from adjacent parts of the plateau.

Some moderately extensive parts of the study area, such as the Nass Depression and sections of Iskut River valley, are characterized by streamlined topography, rather than by ice stagnation features. These may have been areas where other active ice streams persisted during deglaciation.

\section{LATE PHASE}

In some areas, pauses or local readvances occurred during a late phase of Fraser Glaciation. Evidence for this is provided by well-defined recessional moraines that mark the former margins of both ice lobes and valley glaciers. The presence of moraines contrasts with the general absence of equivalent features in southern British Columbia. In the Tuya-Teslin area, numerous examples of recessional moraines indicate that at least one stillstand occurred during the recession of valley glaciers and ice lobes, although the behaviour of the two types of ice-terminii was not synchronous (Watson and Mathews, 1944). Hamilton (1981) noted lateral and "terminal" moraines in most valleys in the Level Mountain Range (Fig. 10). Tallman (1970) recognized several phases of deglaciation based on sets of recessional moraines. Roots (1954) described recessional moraines from many valleys in the Omineca Mountains. Aitken (1959) suggested that alpine glaciers reoccupied cirques in the Atlin area after the last ice sheet disappeared. In places, kame terraces formed along the ice margin during pauses in ice recession (Johnston, 1926a; Watson and Mathews, 1944).

In other localities, active alpine glaciers may not have existed during deglaciation. For example, Gabrielse (1963) noted the absence of local moraines and glacial debris from cirques in the Dease Lake area. Similarly, no Late-Pleistocene moraines have been recognized in the Coast Mountains (Ryder, 1987). 


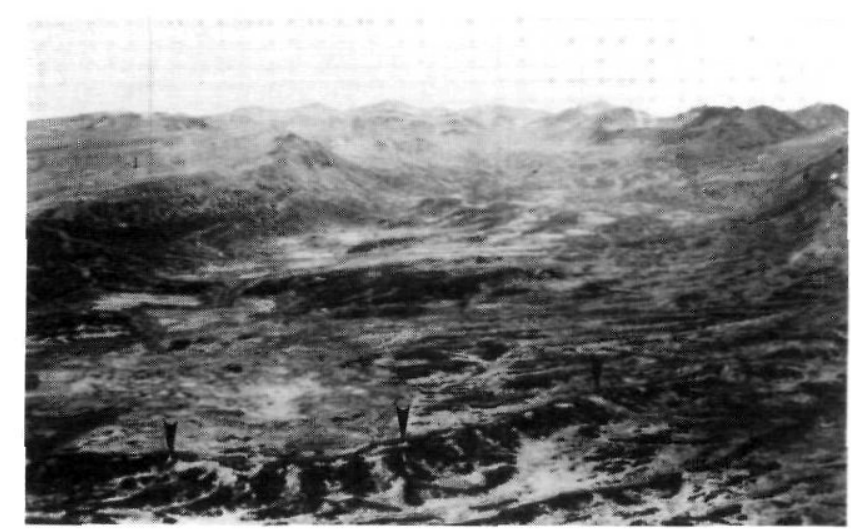

FIGURE 10. Recessional moraine (arrows) in a major southwaradraining valley on the south side of the Level Mountain Range.

Moraines de retrait (flèches) dans une vallée de drainage vers le sud, sur le côté sud de la chaîne Level.

\section{SUMMARY}

The rather limited information that is available about the glacial history of northern British Columbia suggests that the general chronology and style of glaciation is similar to that of the southern part of the province (Ryder et al.,). Some dissimilarities between northern and southern areas exist, however, with regard to specific aspects of the Fraser Glaciation ice sheet:

(1) At the onset of glaciation, ice accumulation areas developed on the higher parts of the intermontane plateaus, as well as on the bordering mountain ranges.

(2) Ice flow indicators show clearly that during the glacial maximum, ice flowed radially from a central névé located over the northern Skeena Mountains.

(3) Similarly, significant drawdown of the ice sheet toward major outlet glaciers is indicated for at least the Stikine and Taku basins.

(4) Evidence of a late glacial stillstand or local readvance is indicated in many areas by widespread recessional moraines.

During what was probably a long, early phase of Fraser Glaciation, Glacial Lake Stikine was impounded by an ice barrier in the Coast Mountains. No evidence of an equivalent recessional lake has been noted. It is proposed that late glacial meltwater escaped via a subglacial conduit beneath a fastflowing and rapidly receding outlet glacier. This process resulted in the initiation of the postglacial Grand Canyon of the Stikine as a tunnel valley.

\section{ACKNOWLEDGEMENTS}

We would like to thank the two anonymous reviewers for their useful comments.

\section{REFERENCES}

Aitken, J. D., 1959. Atlin map-area, British Columbia. Geological Survey of Canada, Memoir 307.

Anderson, J. H., 1970. A geobotanical study in the Atlin region in northern British Columbia and south central Yukon. Ph.D. thesis. Michigan State University, East Lansing, Michigan.
Armstrong, J. E., 1949. Fort St. James map-area, Cassiar and Coast Districts, British Columbia. Geological Survey of Canada, Memoir 252.

Armstrong, J. E. and Tipper, H.W., 1948. Glaciation in north central British Columbia. American Journal of Science, 246: 283-310.

Clague, J. J., 1981. Late Quaternary geology and geochronology of British Columbia. Part 2: Summary and discussion of radiocarbon-dated Quaternary history. Geological Survey of Canada, Paper 80-35.

__ 1989. Cordilleran Ice Sheet, p. 40-42. In R. J. Fulton, ed., Quaternary Geology of Canada and Greenland. Geological Survey of Canada, Geology of Canada, no. 1 (also Geological Society of America, Geology of North America, v. K-1).

Davis, N. F. G. and Mathews, W. H., 1944. Four phases of glaciation with illustrations from southwestern British Columbia. Journal of Geology, 52: 403-413.

Dawson, G. M., 1888. Recent observations on the glaciation of British Columbia and adjacent regions. Geological Magazine, 5: 347-350.

- 1889. Report on an exploration in the Yukon District, N.W.T., and adjacent northern portion of British Columbia. Geological Survey of Canada, Annual Report, new series, vol. 3 (1887-1888) part B: 1-277.

Dyke, W. and Prest, V. K. 1986. Late Wisconsinan and Holocene history of the Laurentide Ice Sheet. Géographie physique et Quaternaire, 41: 237-263.

Fenger, M., 1982. Cry Lake (1041) biophysical inventory (1:250 000 scale map and marginal notes). British Columbia Ministry of Environment, Assessment and Planning Division.

Fulton, R. J., 1969. Glacial lake history, southern Interior Plateau, British Columbia. Geological Survey of Canada, Paper 69-37.

Gabrieise, H., 1963. McDame map-area, Cassiar District, British Columbia. Geological Survey of Canada, Memoir 319.

1968. Geology of the Jennings River map-area, British Columbia. Geological Survey of Canada, Paper 68-55.

Hamilton, T. S., 1981. Late Cenozoic alkaline volcanics of the Level Mountain Range, northwestern British Columbia: geology, petrology and palaeomagnetism. Ph.D. thesis, University of Alberta, Edmonton, Alberta.

Hanson, G., 1929. Bear River and Stewart map-areas, Cassiar District, British Columbia. Geological Survey of Canada, Memoir 159.

1935. Portland Canal area, British Columbia. Geological Survey of Canada, Memoir 175.

Hanson, G. and McNaughton, D. A., 1936. Eagle and McDame area, Cassiar District, British Columbia. Geological Survey of Canada, Memoir 194.

Harington, C. R., Tipper, H. W. and Mott, R. J., 1974. Mammoth from Babine Lake, British Columbia. Canadian Journal of Earth Sciences, 11: 285-303.

Holland, S. S., 1940. Placer gold deposits, Wheaton (Boulder) Creek, Cassiar District, northern British Columbia. British Columbia Department of Mines, Bulletin 2.

1964. Landforms of British Columbia a physiographic outline. British Columbia Department of Mines and Petroleum Resources, Bulletin 48.

Johnston, W. A., 1926a. Gold placers of Dease Lake area, Cassiar District, British Columbia. Geological Survey of Canada, Summary Report 1925, part A: 33-74.

1926b. The Pleistocene of Cariboo and Cassiar Districts, British Columbia, Canada. Transactions of the Royal Society of Canada, Series 3, vol. 20 , section 4 : 137-147.

Kerr, F. A., 1934. Glaciation in northern British Columbia. Transactions of the Royal Society of Canada, 28: 17-31.

1936. Quaternary glaciation in the Coast Range, northern British Columbia and Alaska. Journal of Geology, 44: 681-700.

- 1948. Lower Stikine and western Iskut River areas, British Columbia. Geological Survey of Canada, Memoir 246.

Klassen, R. W., 1987. The Tertiary-Pleistocene stratigraphy of the Liard Plain, southeastern Yukon Territory. Geological Survey of Canada, Paper 86-17. 
Lacelle, L. E. H., 1983. Terrain inventory maps for the Iskut River (104B) and Spatsizi (104H) map-areas (1:250 000 scale). British Columbia Ministry of Environment.

Lambert, M. B., 1974. The Bennett Lake cauldron subsidence complex, British Columbia and Yukon Territory. Geological Survey of Canada, Bulletin 227.

Lay, D. 1940. Aiken Lake map-area, north central British Columbia. British Columbia Department of Mines, Bulletin 1.

Lord, C. S., 1948. McConnell Creek map-area, Cassiar District, British Columbia. Geological Survey of Canada, Memoir 251.

Mathews, W. H. (compiler), 1986. Physiographic map of the Canadian Cordillera. Geological Survey of Canada, Map 1701A, scale 1:5 million.

1980. Retreat of the last ice sheets in northeastern British Columbia and adjacent Alberta. Geological Survey of Canada, Bulletin 331.

McConnell, R. G., 1913. Portions of Portland Canal and Skeena Mining Divisions, Skeena District, British Columbia. Geological Survey of Canada, Memoir 32.

Miller, M. M., 1976. Quaternary erosional and stratigraphic sequences in the Alaska-Canada Boundary Range, p. 463-492. In W. C. Mahaney, ed., Quaternary stratigraphy of North America. Dowden, Hutchinson and Ross, Inc., Stroudsburg (Pennsylvania).

Prest, V. K., Grant, D. R. and Rampton, V. N., 1967. Glacial map of Canada. Geological Survey of Canada, Map 1253A.

Read, P. B., Geotex Consultants, Ltd., Vancouver, British Columbia.

Roots, E. F., 1954. Geology and mineral deposits of Aiken Lake map-area, British Columbia. Geological Survey of Canada, Memoir 274.
Rutter, N., 1977. Multiple glaciation in the area of Williston Lake, British Columbia. Geological Survey of Canada, Bulletin 273.

Ryder, J. M., 1981. Terrain inventory map for the Dease Lake (104J) map-area (1:250 000 scale). British Columbia Ministry of Environment.

- 1983. Terrain inventory map for the Telegraph Creek (104G) map-area (1:250 000 scale). British Columbia Ministry of Environment.

1987. Neoglacial history of the Stikine-Iskut area, northern Coast Mountains, British Columbia. Canadian Journal of Earth Sciences, 24: 1294-1301.

Ryder, J. M. and Clague, J. J., 1989. British Columbia (Quaternary stratigraphy and history, Cordilleran Ice Sheet), p. 48-58. In R. J. Fulton, ed., Quaternary Geology of Canada and Greenland. Geological Survey of Canada, Geology of Canada, no. 1 (also Geological Society of America, Geology of North America, v. K-1).

Ryder, J. M., Fulton, R. J. and Clague, J. J., 1991. The Cordilleran Ice Sheet in southern and central British Columbia. Géographie physique et Quaternaire, 45 (3):

Souther, J. G., Armstrong, R. L. and Harakal, J., 1984. Chronology of the peralkaline, late Cenozoic Mount Edziza complex, northern British Columbia, Canada. Geological Society of America, Bulletin, 95: 337-349.

Tallman, A. M., 1975. Glacial and periglacial geomorphology of the Fourth of July Creek valley, Atlin Region, Cassiar District, northwestern British Columbia. Ph.D. thesis, Michigan State University, East Lansing, Michigan.

Watson, K. de P. and Mathews, W. H., 1944. The Tuya-Teslin area, northern British Columbia. British Columbia Department of Mines, Bulletin 19.

Wheeler, J. O., 1961. Whitehorse map-area, Yukon Territory. Geological Survey of Canada, Memoir 312. 